\title{
Morphological integrity of the bronchial epithelium in mild asthma
}

\author{
S Lozewicz, C Wells, E Gomez, H Ferguson, P Richman, J Devalia, R J Davies
}

\begin{abstract}
In severe asthma bronchial epithelial cells are damaged and detached, and it has been proposed that such damage might lead to the bronchial hyperresponsiveness that characterises asthma. To investigate the relation between airway hyperresponsiveness and epithelial damage, biopsy specimens of the bronchial mucus membrane were obtained at fibreoptic bronchoscopy from 11 patients with mild atopic asthma and airway hyperresponsiveness (provocative concentration of methacholine causing a $20 \%$ fall in FEV $\left(\right.$ PC $\left._{20}\right)$ $<1.0 \mathrm{mg} / \mathrm{ml}$ ), and from 17 healthy nonatopic subjects who did not have airway hyperresponsiveness $\left(\mathbf{P C}_{20}\right.$ methacholine $>8.0 \mathrm{mg} / \mathrm{ml}$ ). Observers who were blind to the presence or absence of asthma examined the biopsy specimens by light and electron microscopy. Epithelial cells, intercellular spaces, and goblet cells were counted. Intercellular junctional complexes were examined, and a semiquantitative assessment was made of ciliary loss, non-parallel central ciliary filaments, and vacuoles in ciliated cells. There were no differences between the asthmatic and healthy groups in any of these measurements. These findings indicate that airway hyperresponsiveness may be present when there is no apparent change in the structure of the bronchial epithelium.
\end{abstract}

Postmortem studies of patients dying from severe asthma show epithelial damage, with oedema and detachment of cells into the bronchial lumen. ${ }^{12}$ Clusters of epithelial cells in the sputum are more common in asthmatic patients than in non-asthmatic control subjects, and more epithelial cells are present in the sputum of patients with more severe asthma. ${ }^{3}$ These findings suggest a link between asthma and damage to the bronchial epithelium, and several mechanisms have been proposed ${ }^{4-7}$ by which such damage might lead to the increased bronchial responsiveness characteristic of asthma. ${ }^{8}$ It has been suggested that stimulation of exposed sensory nerve endings in the airway wall by inflammatory mediators might activate an axon reflex with the subsequent release of sensory neuropeptides that produce or contribute to the pathological changes in asthma. ${ }^{4}$ Alternatively, epithelial damage may cause bronchial hyperresponsiveness through the production of inflammatory mediators by epithelial cells ${ }^{6}$ or by a reduction in epithelium derived smooth muscle relaxant factor. ${ }^{7}$

To investigate the relation between airway hyperresponsiveness and epithelial damage further we have used light and electron microscopy to examine the epithelium in bronchial biopsy specimens taken from patients with mild asthma and airway hyperresponsiveness, and from healthy non-asthmatic subjects who did not show airway hyperresponsiveness.

\section{Methods}

PATIENTS

We studied 11 asthmatic patients (mean age 24 years; three male) and 17 healthy nonasthmatic volunteers (mean age 26 years; seven male). All the asthmatic patients showed airway hyperresponsiveness to inhaled methacholine-that is, a $20^{\circ}{ }_{0}$ fall in $\mathrm{FEV}_{1}$ after inhalation of a concentration $\left(\mathrm{PC}_{20} \mathrm{FEV}_{1}\right)$ of methacholine of $4.0 \mathrm{mg} / \mathrm{ml}$ or less. All the asthmatic patients had a $\mathrm{PC}_{20} \mathrm{FEV}_{1}$ less than 1 $\mathrm{mg} / \mathrm{ml}$ and all the non-asthmatic subjects had a value greater than $8 \mathrm{mg} / \mathrm{ml}$. All the asthmatic patients (and none of the non-asthmatic subjects) were atopic on the basis of one or more positive skinprick test responses to five common inhalant allergens: housedust $\left(150^{\circ}{ }_{0}\right.$ $\mathrm{w} / \mathrm{v})$, Dermatophagoides pteronyssinus $(1.2 \%$ $\mathrm{w} / \mathrm{v})$, mixed grass pollens $(2.5 \% \mathrm{w} / \mathrm{v})$, cat fur $(150 \% \mathrm{w} / \mathrm{v})$, and $\operatorname{dog}$ hair $(150 \% \mathrm{w} / \mathrm{v})$ (Bencard, Brentford, Middx). The asthmatic patients all had mild disease with intermittent symptoms, and none required treatment with inhaled or oral corticosteroids. All subjects were non-smokers and none gave a history of upper respiratory tract infection during the four weeks before the study. Subjects' characteristics, including treatment requirements, are detailed in table 1. Approval was obtained from the ethics committee of St Bartholomew's Hospital and informed consent was obtained from each subject.

Biopsy specimens from 10 of the asthmatic patients and nine of the healthy subjects (identified in table 1) were examined by light microscopy. The mean maximum $\mathrm{FEV}_{1}$ was $96.9 \%$ predicted in the asthmatic patients and $96.1 \%$ in the non-asthmatic subjects.

Biopsy specimens from eight of the asthmatic patients and 10 of the healthy subjects (identified in table 1) were studied by electron microscopy. The mean $\mathrm{FEV}_{1}$ was $91.1 \%$ predicted in the asthmatic patients and $100 \cdot 4^{\circ}{ }_{0}$ in the non-asthmatic subjects. Dr R J Davies, St Bartholomew's Hospital

Accepted 20 October 1989 
Table 1 Subjects' characteristics

\begin{tabular}{|c|c|c|c|c|c|c|c|c|}
\hline \multirow{2}{*}{$\begin{array}{l}\text { Subject } \\
\text { no }\end{array}$} & \multirow[b]{2}{*}{ Age (y) } & \multirow[b]{2}{*}{ Sex } & \multirow[b]{2}{*}{ Atopy } & \multirow{2}{*}{$\begin{array}{l}F E V_{1} \\
(\% \text { pred })\end{array}$} & \multirow{2}{*}{$\begin{array}{l}P C_{20} F E V, \text { methacholine } \\
(\mathrm{mg} / \mathrm{ml})\end{array}$} & \multirow[b]{2}{*}{ Treatment } & \multicolumn{2}{|c|}{ Biopsy specimen for } \\
\hline & & & & & & & $L M$ & $E M$ \\
\hline \multicolumn{9}{|c|}{ ASTHMATIC PATIENTS } \\
\hline 1 & 26 & $\mathbf{F}$ & + & 100 & 0.08 & S & + & + \\
\hline 2 & 21 & $\mathbf{F}$ & + & 85 & 0.02 & $S+S C G$ & + & + \\
\hline 3 & 22 & $\mathrm{~F}$ & + & 73 & $0 \cdot 18$ & $\mathbf{S}$ & + & + \\
\hline 4 & 20 & $\mathbf{M}$ & + & 80 & $0 \cdot 11$ & $S+T$ & + & + \\
\hline 5 & 21 & M & + & 97 & 0.27 & $S+S C G$ & + & + \\
\hline 6 & 25 & $\mathbf{M}$ & + & 105 & 0.80 & $S+S C G$ & + & + \\
\hline 7 & 27 & $\mathbf{F}$ & + & 100 & $0 \cdot 10$ & $\mathbf{S}$ & + & + \\
\hline 8 & 22 & $\mathbf{F}$ & + & 110 & 0.01 & $\mathbf{S}$ & + & - \\
\hline 9 & 32 & $\mathbf{F}$ & + & 105 & 0.05 & $\mathbf{S}$ & + & - \\
\hline 10 & 26 & $\mathbf{F}$ & + & 114 & 0.50 & $\mathbf{S}$ & + & - \\
\hline 11 & 23 & F & + & 89 & $0^{\star}$ & $\mathbf{S}$ & - & + \\
\hline Mean & $24 \cdot 1$ & & & $96 \cdot 2$ & & & & \\
\hline \multicolumn{9}{|c|}{ HEALTHY SUBJECTS } \\
\hline 12 & 34 & $\mathbf{F}$ & - & 88 & $>8 \cdot 0$ & - & - & + \\
\hline 13 & 23 & $\mathbf{F}$ & - & 113 & $>8.0$ & - & - & + \\
\hline 14 & 30 & F & - & 109 & $>8.0$ & - & - & + \\
\hline 15 & 21 & $\mathrm{~F}$ & - & 71 & $>8.0$ & - & - & + \\
\hline 16 & 25 & $\mathbf{F}$ & - & 110 & $>8.0$ & - & - & + \\
\hline 17 & 27 & $\mathbf{M}$ & - & 105 & $>8.0$ & - & - & + \\
\hline 18 & 23 & F & - & 98 & $>8.0$ & - & - & + \\
\hline 19 & 21 & $\mathbf{F}$ & - & 85 & $>8.0$ & - & + & - \\
\hline 20 & 27 & $\mathbf{M}$ & - & 112 & $>8.0$ & - & + & - \\
\hline 21 & 21 & $\mathbf{M}$ & - & 107 & $>8.0$ & - & + & - \\
\hline 22 & 29 & $F$ & - & 102 & $>8.0$ & - & + & - \\
\hline 23 & 39 & M & - & 93 & $>8.0$ & - & + & - \\
\hline 24 & 39 & M & - & 89 & $>8.0$ & - & + & - \\
\hline 25 & 24 & M & - & 87 & $>8.0$ & - & + & - \\
\hline 26 & 22 & F & - & 93 & $>8.0$ & - & + & + \\
\hline 27 & 26 & F & - & 97 & $>8.0$ & - & + & + \\
\hline 28 & 22 & $\mathbf{M}$ & - & 120 & $>8.0$ & - & - & + \\
\hline Mean & $26 \cdot 6$ & & & $98 \cdot 8$ & & & & \\
\hline
\end{tabular}

*Inhalation of normal saline produced a $20^{\circ}$, fall in $\mathrm{FEV}_{1}$

$S-$ inhaled salbutamol; SCG-sodium cromoglycate; T-slow release theophylline tablets; LM-light microscopy; EMelectron microscopy.

\section{STUDY DESIGN}

Fibreoptic bronchoscopy was performed with an Olympus BF type 10 bronchoscope (Keymed, Southend-on-Sea, Essex) after premedication with intramuscular papaveretum $10-20 \mathrm{mg}$ and scopolamine $0 \cdot 2-0 \cdot 4$ mg. Local anaesthesia was achieved with $4^{\circ}{ }_{0}$ lignocaine (Biorex, London), of which $6 \mathrm{ml}$ was applied to the larynx above the vocal cords and $2 \mathrm{ml}$ instilled into the right main bronchus. Cup forceps were used to take up to two biopsy specimens of the mucus membrane from the right upper and right middle lobe carinas. Bronchoscopy and biopsy were carried out according to the American Thoracic Society's guidelines. ${ }^{9}$

Patients were asked to stop inhaled treatment 12 hours before and oral medication 24 hours before the methacholine inhalation test, ${ }^{10}$ which in all cases was performed between 13.00 and 16.00 hours. In seven individuals the methacholine inhalation test was performed seven to 14 days after the bronchoscopy and in 21 it was done the day before bronchoscopy.

FIXATION AND STAINING OF BIOPSY SPECIMENS Biopsy specimens for light microscopy were placed immediately in $10^{\circ}{ }_{0}$ buffered formaldehyde for three hours. They were then embedded in wax and sectioned at $4 \mu \mathrm{m}$ thickness. Sections were stained with haematoxylin.

Biopsy specimens for transmission electron microscopy were fixed immediately in $3^{\circ} \mathrm{o}$ glutaraldehyde in 0.1 molar cacodylate buffer, postfixed in $1 \%$ osmium tetroxide, block stained in saturated aqueous uranyl acetate, and embedded in TAAB Premix resin (medium).
EXAMINATION OF BIOPSY SPECIMENS

The sections prepared for light microscopy were all examined by the same observer (PR), Sections prepared for electron microscopy were examined independently by a separate observer (CW). Both observers were blind to the presence or absence of asthma.

Light microscopy was used to assess goblet cell hyperplasia, epithelial cell loss, squamous metaplasia, and epithelial cell swelling, all of which have previously been described in biopsy specimens taken at bronchoscopy from patients with asthma. ${ }^{112}$ Goblet cell hyperplasia was estimated by counting 20 epithelial cells in each of two representative areas of epithelium. The number of goblet cells was counted in each area and the mean value (expressed as number of goblet cells per 20 epithelial cells) recorded for each patient. Loss of epithelial cells was assessed by using the Hewlett Packard computerised Imagen system to measure the area of epithelium (A) and corresponding length of basement membrane (l) in each tissue section. The mean epithelial height was computed as $\mathrm{A} / 1$ and provided an index that is diminished by loss of epithelial cells.

Ultrastructural changes previously described in asthmatic patients ${ }^{12}$ were also assessed. Widening of intercellular spaces was measured on electron micrographs taken at $\times 16800$ magnification by means of the IBAS 2 image analysis system. Measurements were made of the area of intercellular space around six non-adjacent epithelial cells, of which two were near each edge and two were in the central part of the biopsy section. Loss of cilia, nonparallel central ciliary filaments, vacuoles in ciliated cells, and loss of epithelial cells was 
Table 2 Morphological features ${ }^{\star}$ of the bronchial epithelium

\begin{tabular}{lll}
\hline & Median value (range) $\dagger$ \\
\hline LIGHT MICROSCOPY & $\begin{array}{l}\text { Asthmatic subjects } \\
(n=10)\end{array}$ & $\begin{array}{l}\text { Non-asthmatic } \\
\text { subjects }(n=9)\end{array}$ \\
Goblet cells $(\mathrm{No} / 20$ epithelial cells) & $1(0-7)$ & $1(0-4)$ \\
Mean epithelial height $(\mu \mathrm{m})$ & $17 \cdot 6(4 \cdot 1-41 \cdot 0)$ & $14 \cdot 7(10-26 \cdot 7)$ \\
ELECTRON MICROSCOPY & Asthmatic subjects & Non-asthmatic \\
& $(n=8)$ & subjects $(n=10)$ \\
Intercellular area $\left(\mu \mathrm{m}^{2}\right)$ & $4 \cdot 40(1 \cdot 94-8 \cdot 08)$ & $4 \cdot 49(4 \cdot 09-7 \cdot 93)$ \\
Loss of cilia & $0(0-1)$ & $0(0-1)$ \\
Non-parallel central ciliary filaments & $1(1-2)$ & $1(0-1)$ \\
Vacuoles in ciliated cells & $1(0-1)$ & $1(0-1)$ \\
Loss of epithelial cells & $1 \cdot 5(1-2)$ & $1(0-2)$ \\
\hline
\end{tabular}

^See under "Methods" (below) for the grading of electron microscopy features.

tThe differences between the asthmatic and non-asthmatic subjects are not significant (MannWhitney U test)

Table 3 Electron microscopy features ${ }^{\star}$ of bronchial biopsy specimens taken after and before methacholine provocation

\begin{tabular}{|c|c|c|}
\hline & \multicolumn{2}{|c|}{ Median value (range) $\dagger$} \\
\hline & $\begin{array}{l}\text { After } \\
\text { methacholine } \\
(n=11)\end{array}$ & $\begin{array}{l}\text { Before } \\
\text { methacholine } \\
(n=7)\end{array}$ \\
\hline $\begin{array}{l}\text { Intercellular area }\left(\mu \mathrm{m}^{2}\right) \\
\text { Loss of cilia } \\
\text { Non-parallel central ciliary filaments } \\
\text { Vacuoles in ciliated cells } \\
\text { Loss of epithelial cells }\end{array}$ & $\begin{array}{l}4 \cdot 73(3 \cdot 52-8 \cdot 08) \\
0(0-1) \\
1(0-2) \\
1(0-1) \\
1(0-2)\end{array}$ & $\begin{array}{l}4 \cdot 48(1 \cdot 94-6 \cdot 79) \\
0 \cdot 5(0-1) \\
1(1-1) \\
1(1-1) \\
1(1-2)\end{array}$ \\
\hline
\end{tabular}

^See under "Methods" (directly below) for grading system.

$\dagger$ The differences between specimens taken before and after metacholine provocation are not significant.

graded on a semiquantitative scale: $0=$ not present, $1=$ present to a small degree, $2=$ present to a greater degree.

\section{STATISTICAL ANALYSIS}

Results obtained from asthmatic and non-asthmatic subjects were compared by means of the Mann-Whitney U test.

\section{Results}

LIGHT MICROSCOPY

Detachment of epithelial cells was seen in biopsy specimens from both asthmatic and healthy subjects, often at the edges of the specimen. There was no difference between asthmatic and healthy subjects in the quantitative assessment of mean epithelial height (table 2). The length of basement membrane corresponding to the assessed area of epithelium ranged from 386 to 5062 (median 2146) $\mu \mathrm{m}$ in the group as a whole. The numbers of goblet cells were not significantly different in the two groups of subjects (table 2); there was no evidence of squamous metaplasia or swelling of epithelial cells in any of the biopsy specimens.

\section{ELECTRON MICROSCOPY}

There was no difference between asthmatic and non-asthmatic subjects with respect to the area of the intercellular spaces, the degree of loss of cilia, non-parallelism of central ciliary filaments, vacuolation of ciliated cells, or loss of epithelial cells (table 2). Deviation from parallel of the satellites of basal bodies of ciliary cells, as described in asthma, ${ }^{11}$ was seen in only one subject, who was not asthmatic. The presence of epithelial nerves close to the bronchial lumen, also described in asthma, ${ }^{11}$ was seen in one asthmatic and in one nonasthmatic subject. No changes were seen in the cellular junctional complexes in any of the subjects.

Biopsy specimens from 18 subjects were processed for electron microscopy, of whom 11 (six asthmatic and five healthy subjects) underwent bronchial biopsy after methacholine provocation and seven (two asthmatic and five healthy subjects) before provocation. There was no difference between these two groups in any of the epithelial changes assessed by electron microscopy (table 3 ).

\section{Discussion}

It is well recognised from postmortem studies that damage to the bronchial epithelium and detachment of epithelial cells occur in severe asthma, ${ }^{12}$ and several mechanisms ${ }^{4-7}$ have been proposed by which epithelial damage could lead to the increased bronchial responsiveness characteristic of asthma. ${ }^{8}$ Little information, however, is available on the histology of the bronchial epithelium in patients with mild asthma. In the present study all the asthmatic patients had mild disease not requiring treatment with inhaled or oral corticosteroids, though all required inhaled salbutamol and all showed airway hyperresponsiveness to methacholine.

Shedding of bronchial mucosal cells in severe asthma ${ }^{1}$ has been attributed to transudation of oedema fluid from the submucosa, observed histologically as separation of epithelial cells. ${ }^{2}$ In the present study quantitative assessment was made of mean epithelial height, which is diminished by loss of epithelial cells, and intercellular area, which is increased by separation of epithelial cells. These measurements were similar in patients and controls, indicating that neither epithelial oedema nor loss of epithelial cells is a characteristic feature of mild asthma. Jeffrey et $a l^{13}$ studied biopsy specimens of the bronchial mucus membrane from patients with asthma and also found no increase in epithelial oedema, though there was increased loss of epithelial cells in a small subgroup of four symptomatic patients, whose lung function was not described and who may have had relatively severe disease.

Disruption of intercellular tight junctions is a recognised feature of airway epithelial damage in the guinea pig $^{14}{ }^{15}$ and after exposure to histamine in cultured airway epithelial cells, ${ }^{16}$ but little information is available on its occurrence in asthma in man. We found no disruption of intercellular junctional complexes in biopsy material from our asthmatic patients, suggesting that this is not present in mild asthma. Goblet cell hyperplasia has been described previously in patients with asthma of varying severity but has not been quantitatively assessed. ${ }^{11}{ }^{17} \mathrm{We}$ quantified this feature, and its absence in our asthmatic subjects may reflect the mildness of their disease.

Laitinen et al observed bronchial epithelial damage on electron microscopy of biopsy specimens taken at rigid bronchoscopy from 
patients with stable asthma. ${ }^{12}$ The changes included alterations in ciliary structure and vacuolation of ciliated epithelial cells, as well as sloughing of epithelial cells. They proposed that bronchial hyperresponsiveness in asthma could be due to exposure of mucosal afferent nerves to non-specific stimuli or released mediators. Comparison was made, however, with only one non-asthmatic control subject, and three of the eight patients required treatment with corticosteroids, suggesting that they had relatively severe disease. In the present study all the asthmatic patients had mild disease and the numbers of asthmatic and control subjects were similar. We observed the features noted by Laitinen et al in asthmatic patients, but also found them to be present, and to the same extent, in healthy subjects. These features, which were regarded as indicating epithelial damage, are therefore likely to be artefactual and caused by the trauma of the biopsy procedure or the fixation process. The biopsy specimens taken by Laitinen et al at rigid bronchoscopy are likely to have been larger than those in the present study, in which a fibreoptic bronchoscope was used. This difference in biopsy size does not alter the interpretation of our observation that there was no difference in the morphological appearance of biopsy specimens from asthmatic and healthy subjects. The inhalation of methacholine is unlikely to have caused epithelial damage in the subjects who underwent bronchoscopy after the challenge test because there was no difference in the degree of epithelial damage between the subjects who had a methacholine test before the bronchial biopsy and those who had it after.

Bronchial epithelial integrity may also be assessed by measurement of airway permeability. In guinea pig tracheal epithelium injury by agents such as cigarette smoke is associated with disruption of epithelial intercellular tight junctions and increased penetration of solutes applied to the luminal surface into the intercellular space. ${ }^{14}$ If airway hyperresponsiveness is closely linked to epithelial disruption, airway hyperresponsiveness might be expected to be associated with increased pulmonary epithelial permeability. In patients with stable asthma and airway hyperresponsiveness to histamine, however, lung epithelial permeability is no greater than in healthy subjects. ${ }^{18} 19$ These findings are in keeping with our observation that changes in intercellular junctions were not present in patients with mild asthma, and support our conclusion that airway hyperresponsiveness may be present in patients with mild asthma in the absence of apparent morphological change in the bronchial epithelium. Our findings also suggest that damage to the bronchial epithelium with consequent exposure of sensory nerve endings is not a determinant of bronchial hyperresponsiveness in patients with mild asthma. Possibly bronchial hyperresponsiveness in patients with mild asthma results from epithelial damage that causes no morphological change, but leads to production of inflammatory mediators by epithelial cells ${ }^{6}$ and a reduction in epithelium derived smooth muscle relaxant factor. ${ }^{7}$

In conclusion, assessment of the degree of bronchial epithelial damage with both electron and light microscopy by observers who were blind to the presence or absence of asthma showed no differences between healthy subjects with normal airway responsiveness and asthmatic patients with airway hyperresponsiveness. These findings indicate that airway hyperresponsiveness may be present when there is no apparent morphological change in the structure of the bronchial epithelium.

1 Dunnill MS. Pulmonary pathology. London: Churchill Livingstone, 1987:61-79.

2 Dunnill MS. The pathology of asthma, with special reference to changes in the bronchial mucosa. J Clin

3 Naylor B. The shedding of the mucosa of the bronchial tree in asthma. Thorax 1962;17:69-72.

4 Barnes PJ. Asthma as an axon reflex. Lancet 1986;i:242-5.

$5 \mathrm{Hogg}$ JC. Is asthma an epithelial disease? Am Rev Respir Dis 1984;129:207-8.

6 Holtzman MJ, Aizawa H, Nadel JA, Goetzl EJ. Selective generation of leukotriene B4 by tracheal epithelial cells
from dogs. Biochem Biophys Res Comm 1983;114:1071-6.

7 Barnes PJ, Cuss FM, Palmer JB. The effect of airway epithelium on smooth muscle contractility in bovine epithelium on smooth muscle contractili
trachea. $B r J$ Pharmacol 1985;86:685-91.

8 Curry JJ. The action of histamine on the respiratory tract in normal and asthmatic subjects. J Clin Invest 1946;25: 785-91.

9 Summary and recommendations of a workshop on the investigative use of fibreoptic bronchoscopy and bronchoalveolar lavage in asthmatics. Am Rev Respir Dis 1985;132:180-2.

10 Chai H, Farr RS, Froehlich LA, et al. Standardization of bronchial inhalation challenge procedures. J Allergy Clin Immunol 1975;56:323-7.

11 Glynn AA, Michaels L. Bronchial biopsy in chronic bronchitis and asthma. Thorax 1960;15:142-53.

12 Laitinen LA, Heino M, Laitinen A, Kava T, Haahtela $T$. Damage of the airway epithelium and bronchial reactivity in patients with asthma. Am Rev Respir Dis 1985;131: 599-606.

13 Jeffery PK, Nelson FC, Wardlaw A, Kay AB, Collins JV. Quantitative analysis of bronchial biopsies in asthma [abstract]. Am Rev Respir Dis 1987;135:A316.

14 Simani AS, Inoue S, Hogg JC. Penetration of the respiratory epithelium of guinea pigs following exposure to cigarette epithelium of guinea pigs followin
smoke. Lab Invest 1974;31:75-81.

15 Boucher RC, Johnson J, Inoue S, Hulbert W, Hogg JC. The effect of cigarette smoke on the permeability of guinea pig airways. Lab Invest 1980;43:94-100.

16 Devalia J, Sapsford R, Wells C, Davies RJD. The effect of histamine and allergen on intercellular junctional complexes in human bronchial epithelial cells in vitro [abstract]. New England Regional Allergy Proceedings 1988;9:447.

17 Salvato G. Some histological changes in chronic bronchitis and asthma. Thorax 1968;23:168-72.

18 Elwood RK, Kennedy S, Belzberg A, Hogg JC, Paré PD. Respiratory mucosal permeability in asthma. Am Rev Respir Dis 1983;128:523-7.

19 O'Byrne PM, Dolovich M, Dirks R, Roberts RS, Newhouse MT. Lung epithelial permeability: relation to nonspecific airway responsiveness. J Appl Physiol: Respirat Environ Exercise Physiol 1984;57:77-84. 